\title{
天竜川の河口フロントと河口地形の観測 \\ River Front and Morphology Observed at the Mouth of River Tenryu
}

\author{
武若 聡 $^{1} \cdot$ 高橋 悠 $^{2} \cdot{\text { 高橋 } \text { 亮 }^{3} \cdot \text { 田島芳満 }}^{4} \cdot$ 佐藤顚司 $^{5}$ \\ Satoshi TAKEWAKA, Yu TAKAHASHI, Ryo TAKAHASI, Yoshimitsu TAJIMA and Shinji SATO
}

\begin{abstract}
An X-band nautical radar system was employed to observe behavior of river front and morphologies at the mouth of River Tenryu, Shizuoka, Japan. Sand bar at the river mouth breached due to flooding during the attack of a Typhoon in July, 2007. The breached part was buried gradually and sand bar showed a recovery in the following 18 months. Streaks of river fronts are captured frequently in the averaged radar images and this was confirmed by a field measurement showing waters with different characteristics met along the streak. Statistics on the appearance of the streaks in the radar images show that fronts developed well when the tide is ebbing. Depths of the river mouth were estimated from the wave speeds. Response of the water level variations of the river channel and tide with the change of river width is shown.
\end{abstract}

\section{1. 緒言}

天竜川ダム再編事業（浜松河川国道事務所, 参照 2009-05-06）の推進により海域への土砂供給増加が期待 されており，これを沿岸に波及させるための検討が必要 である。この一環として，Xバンドレーダを用い，天竜 川河口の地形と流動に関する連続観測を実施している (武若ら, 2008). 本研究では河口地形の変化を示し, 河 ロフロントの観測, レーダで捉えた河ロフロントの挙動, 河口水深の推定, 河口幅と河川内水位 - 潮汐応答に関す る解析を行い, 河口域の土砂移動, 流動の特徵を説明する.

\section{2. 観測の概要}

天竜川河口右岸にある下水処理施設の屋上にXバンド レーダを設置し観測を2007年6月より開始し，2009年5 月時点で継続している。レーダ画像には波の進行状況, 水際位置などが映る。図-1に観測サイト，座標系，レー ダ原画像を時間平均化した平均画像などを示す。座標系 は平面直角座標系（VIII系）を参考に，東西方向に $x$ 軸， 南北方向に $y$ 軸を設定した。平均画像は解析に用いる部 分を取り出して表示してある。輝度値の大きい部分が陸 域に対応しており, 河道内の砂州, 河口, 河口砂州の水 際位置, 河口フロントの発生などの状況を判読できる. 下水処理施設内にある塔が妨げとなってレーダエコーを 取得できない領域が扇状に広がっている. 平均画像の処

\footnotetext{
1 正会員 工博 筑波大学准教授大学院システム情報工学 研究科

2 修(工) 伊藤忠テクノソリューションズ

3 学生会員 筑波大学大学院システム情報工学研究科

4 正会員 博(工) 東京大学准教授大学院工学系研究科

5 フェロー 工博 東京大学教授大学院工学系研究科
}

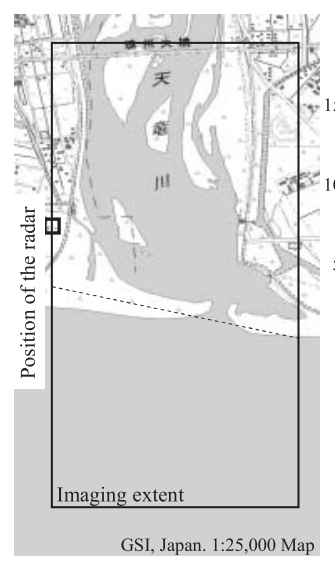

(a)

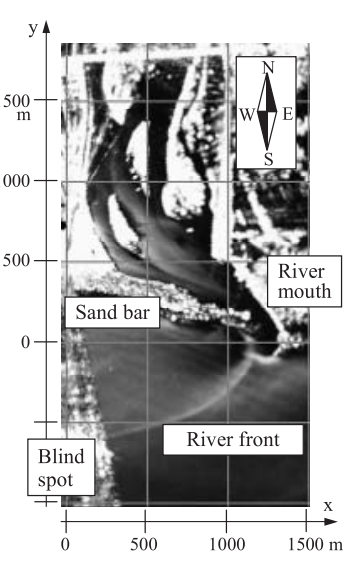

(b)
図-1 レーダの設置位置と観測範囲。（a）観測領域，(b) 座標 系と平均画像（2007年6月 8 日 21 時. 潮位（御前崎）： $0.08 \mathrm{~m}$. 河口フロントの強度 [2] )

理と解析に関する基本的な確認は前報（武若ら，2008） にある。

\section{3. 河口地形の変化}

平均画像を解析し，2007年7月の出水により河口砂州 が決壊し（田島ら，2008），その後の2008年12月まで， 河口砂州の決壊部が閉じる過程, 河口幅の変化などを追 跡した. 図-2に砂州の決壊とその後の地形変化を示す.

2007 年 6 月から 2008 年 12 月の間の潮位（御前崎, 河口 から東方約 $40 \mathrm{~km}, \mathrm{~T}$. P. 值) が $0.3 \sim 0.4 \mathrm{~m}$ にあった時に 取得された平均画像を選択し, 水際位置を読み取った。 欠測期間を除くと，選択した画像が取得された日時の間 隔はおおよそ3日である。

河口砂州を含む河口部の面積変化を次の手順で求めた. 


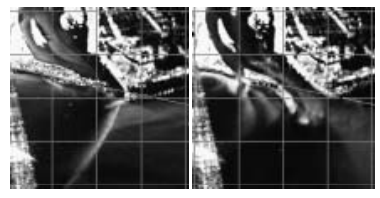

2007/06/30 21h 2007/07/18 18h $0.37 \mathrm{~m},[2]$

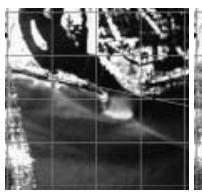

$2007 / 08 / 22$

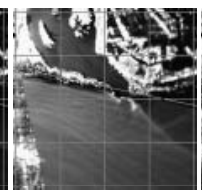

$2007 / 11 / 21$
$0.33 \mathrm{~m},[2]$

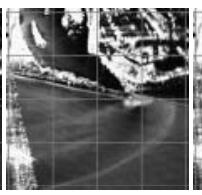

2008/03/14 07h

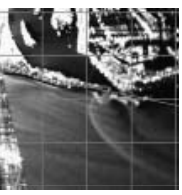

$2008 / 06 / 14$
$0.33 \mathrm{~m},[2]$
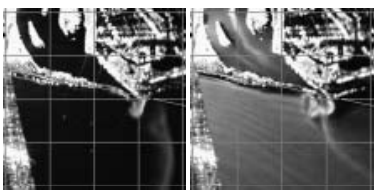

2008/10/03 21h 2008/12/18 13h $0.36 \mathrm{~m},[1] \quad 0.32 \mathrm{~m},[2]$

図-2 河口地形の変化と河口フロントの発達.

2 行目の数值は潮位 (御前崎). [ ] 内の数字：河口フロント強度. 1 マスの大きさは $500 \mathrm{~m} \times 500 \mathrm{~m}$.

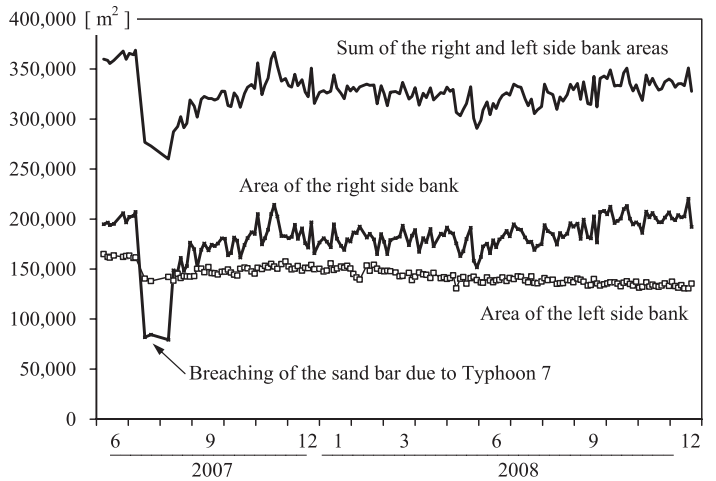

図-3 河口域地形の面積変化

width of river mouth $[\mathrm{m}]$

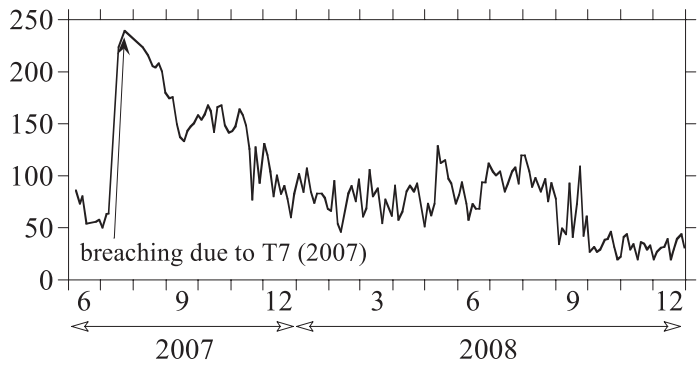

図-4 河口幅の変化

各平均画像から, $0<x<1500 \mathrm{~m}, 0<y<500 \mathrm{~m}$ の範囲（総面 積 $750,000 \mathrm{~m}^{2}$ ) にある水際位置を読み取り, 右岸陸域, 河口砂州，左岸陸域の面積を算定した。図-3に2007年6 月 8 日以降の（A）右岸部陸域と河口砂州を合わせた面 積, （B）左岸部陸域面積, （C）両者の和の経時変化を示 す. 砂州決壊後, 河口砂州部の面積は決壊前とほぼ同じ 状況まで回復したのに対して, 左岸の河口部は回復がほ とんど無かった。ここは, 河川流の澪筋となっており, 砂が堆積することができなかったと考えられる.

図-4に河口幅の変化を水際位置の座標から算出した結 果を示す. 河口幅は砂州開口部の最小幅として定義して あるので，その位置は常に変動する，砂州決壊後，ほほ 半年を経て河口幅は出水前と同じ規模となり，2008年末 の時点で $30 \mathrm{~m}$ 程度となった。

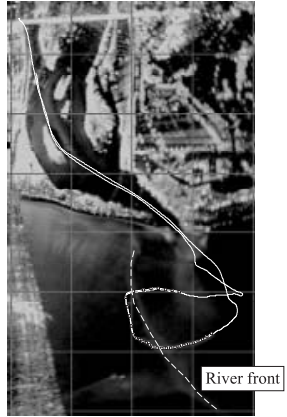

(a)

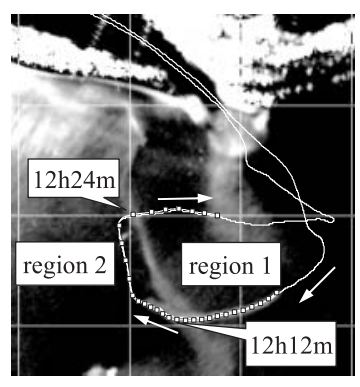

(b)
図-3 2008年7月 24 日 12 時. 航跡と河口フロントの位置関係. (a) 平均画像と全航跡, (b) 河口フロント付近の航跡. 斜め右下方向に延びる筋が河口フロント， $\square: 12$ 時 00 分から 30 分までの1分毎の船の位置.

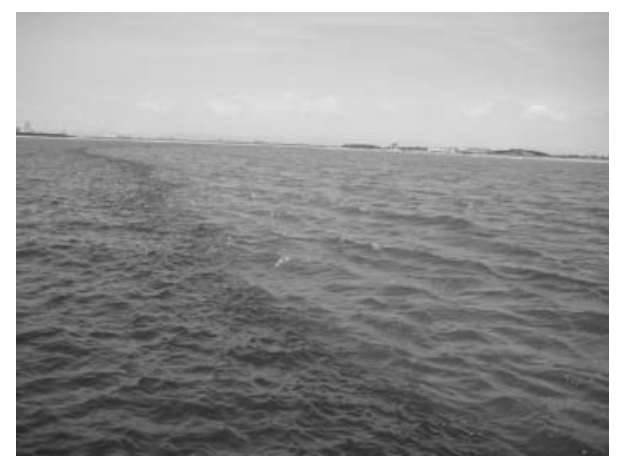

写真-1 船上から観察された河口フロント. 撮影時刻 12 時 11 分. 北北西を向いて撮影. 右方：領域 1 , 左方 : 領域 2.

\section{4. 河ロフロント}

レーダ平均画像には頻繁に筋状のパターンが捉えら れ，河川水が海域に貫入して形成される河口フロントの ように見える（図-2）. 前報（武若ら，2008）では衛星可 視画像を用い, 平均画像に現れる筋状のパターンと河口 フロントとの対応を確かめたが，ここではフィールド観 測と統計解析により確認を深める.

\section{（1）河ロフロントのフィールド観測}

2008 年 7 月 24 日の午前中に, 平均画像に映る筋状のパ ターン周辺で計測器を曳航し, 水温の鉛直分布（サーミ 


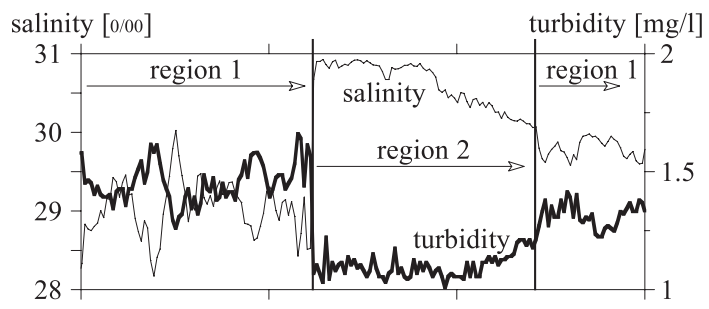

$12 \mathrm{~h} \mathrm{00m} \quad 12 \mathrm{~h} 10 \mathrm{~m} \quad 12 \mathrm{~h} 20 \mathrm{~m} \quad 12 \mathrm{~h} 30 \mathrm{~m}$

(a)

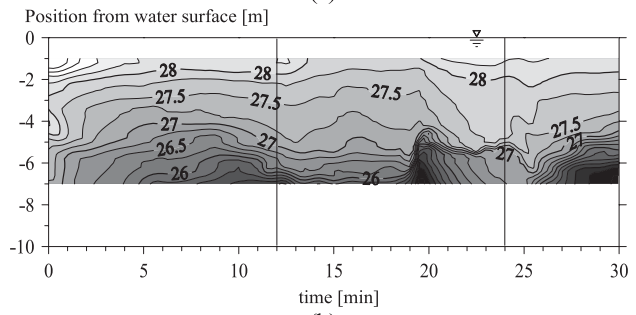

(b)

図-6（a）塩分・濁度，（b）水温鉛直分布の時間変化.

スタチェーン), 塩分・濁度（水面下約 $2 \mathrm{~m}$, アレック電 子 CTD), 流速分布（NORTEK AWAC）を観測した。観 測中は快晴, 微風であり, 波はほとんどなかった.

図-5に平均画像と航跡を示す。河口沖合に発達した筋 状パターンを 2 回横切った (12 時 12 分頃, 24分頃). 写 真-1 は筋状パターンを横切った時に, 船上から河口砂州 方向を望み撮影したもので, 海面色, 波立ち状況に不連 続が観られ，いわゆる潮目の形成が確認された。

塩分・濁度，水温の鉛直分布の観測結果を図-6に示す. 河川水の影響が大きいと考えられる領域 1 の塩分は相対 的に低く，また，濁度は高い。水温分布の観測結果には 日射により発達した温度成層が捉えられている。船が領 域 2 から 1 に向い，筋状パターンを横切る際（12 時20分 〜25分）に，上層の暖水が下方に巻き达まれている様子 がうかがえ，この付近に下降流があったことが示唆され る.ただし，流速計の観測結果にはこの鉛直方向の流れ は現れなかった。

流れの大きさは全般に小さく $(0.5 \mathrm{~m} / \mathrm{s}$ 以下 $)$, 向きは 全般的に南方に向いていた. 筋状パターンの周辺で流速 分布に顕著な変化は見られなかった。

以上より, 平均画像に映るパターンは河川水と海水が 混合する境界, 河口フロントであると判断した。このパ ターン付近では流れが収束しており，ここに到達した波 が周辺域と比較して急峻になり，レーダに高輝度部とし て捉えられたと考えている。

\section{（2）河ロフロントの発生強度}

平均画像に映る河口フロントの鮮明さは変動してい た。これをフロントの強度として，2007年6月から 2008 年 5 月に取得された平均画像（8,593枚）を判読し, 目視

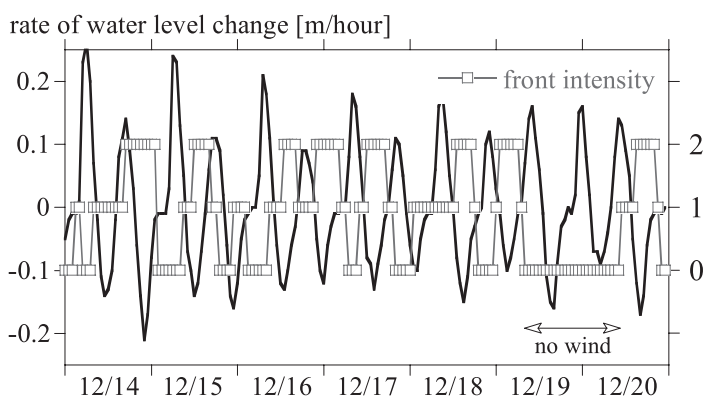

図-7 河川水位変化速度とフロント強度 $(0,1,2)$ の変化 2007 年12月 14 日 - 12 月 20 日.

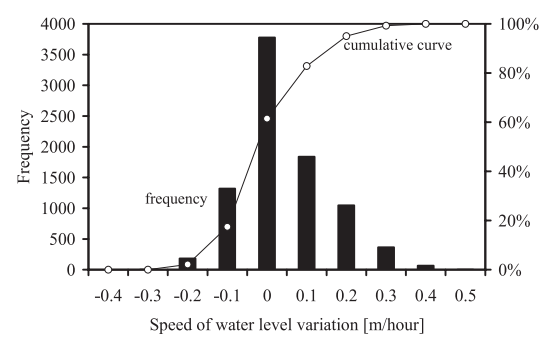

(a)

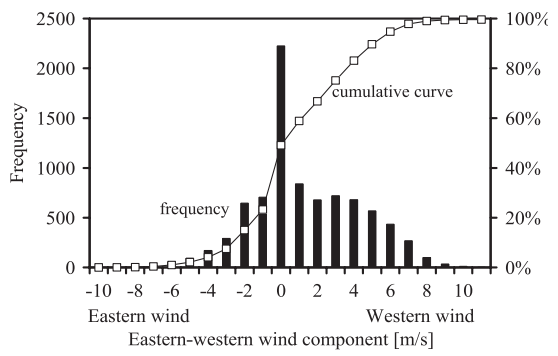

(b)

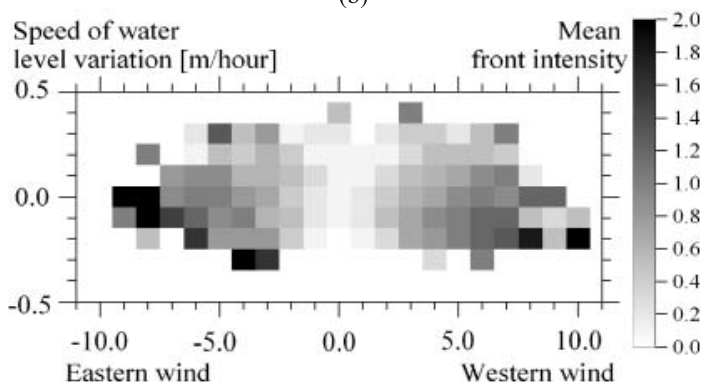

Eastern-western wind component $[\mathrm{m} / \mathrm{s}]$

(c)

図-8（a）河川水位変化速度の頻度分布，（b）東西方向風速 成分の頻度分布，（c）河川水位変化速度-東西方向風速 成分毎のフロント強度. 全イベント数：8,593.

で3段階（0，1，2）に分類した（図-2）。この結果と感 潮区間の河川水位（河口から約 $3 \mathrm{~km}$, 掛塚橋), 風向 · 風速（アメダス, 磐田), 河川幅（レーダ観測）との関 係を調べた。

ここで, 平均画像の明るさは, 強風時, 高波浪時, 降 
雨時などに上昇する傾向にあり, 目視により読み取る強 度は筋状パターンの画像内の相対的な鮮明さであること に注意が必要である. 本研究では著者の内の 1 名が読み 取り作業を行っており, 強度の判定が主観的であること は否めない. しかしながら, 次に説明する河川水位の変 化速度と読み取った強度の結果を整合的に説明できるこ とから，一定の信頼性はあると判断している．輝度分布 を解析し, 強度を判定するアルゴリズムの検討を行った が, 沉用性をもたせるには至らなかった。

河口フロントの強度は, 河川内の水位が低下する時, すなわち，流れが河川から海域に向かうときに大きくな る（図-7）。しかしながら，図中に示したように，風が弱 い時間帯には水位が低下する時間帯にも関わらず河口フ ロントが映っていない.

そこで, 風速・風向, 河川内の水位変化と河口フロン 卜強度の関係を調べた. 図-8に風速の東西方向成分（西 からの風を正に定義）と河川水位変化速さの頻度分布, 風速・河川水位変化の速度の各階級とフロント強度の平 均值の関係を示す。風速が扔打よそ $3 \mathrm{~m} / \mathrm{s}$ 以上，風向が東 西方向に延びる海岸線に平行である時, 河川水位が低下 している時にフロント強度が大きくなり，これ以外の風 向・風速条件の下でフロントの強度, 観られる回数は相 対的に小さかった。これは, レーダが海面に発達する波 を捉えており，電波送信方向と波の進行方向が一致する 時に波が鮮明に映ることによる，風向が海岸線に直交す る時間帯, 風速が小さい時間帯にも河川水フロントは発 生していると思われるが，現在のレーダ設置位置では捉 えることが難しい. な拀, 河川幅の広狭とフロント強度 には関倸性が見られなかった。

\section{5. 河口水深変化の推定と河川水位-潮汐応答の変化}

\section{（1）河口水深変化の推定}

河口を進行する波の速さをレーダ画像から読み取り， 河口水深を推定し, 河口幅および河口断面積（河口幅 $\times$ 河口水深）の変化を調べた.

レーダ原画像（図-9）には，比較的波高が大きい時 （お抢よそ $3 \mathrm{~m}$ 以上）に，海から河口に到達する波が映る. このとき波は順流あるいは逆流上を進行している. 海域, 河口部中心, 河道内を通る線を設け, 輝度值の時間変化 を調べ, 時間 $i$ に打ける河口部を通過する波の波速 $C_{R i}$ を 求めた.この波速が, 潮汐の入退による流れ, 河川流に よる影響を受けたものとして，次の手順で河口域の平均 的な水深 $h$ を推定した.

時間 $i$ の御前崎（河口から東方約 $40 \mathrm{~km}$ ）の潮位を $\eta_{O i}$, 掛塚橋（河口から上流約 $3 \mathrm{~km}$, 感潮域内）の水位を $\eta_{K}$, 河口から約 $25 \mathrm{~km}$ に位置する鹿島橋流量を $Q_{i}$, 平均画像 から読み取った河口幅を $B$ とする。水深 $h$ および感潮域

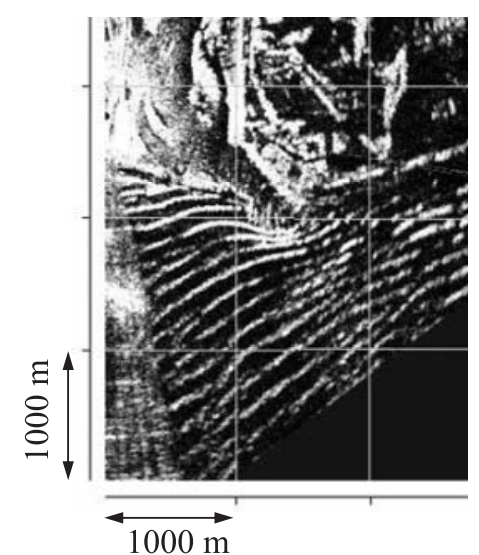

図-9 レーダ原画像（2007年9月5日 17時）

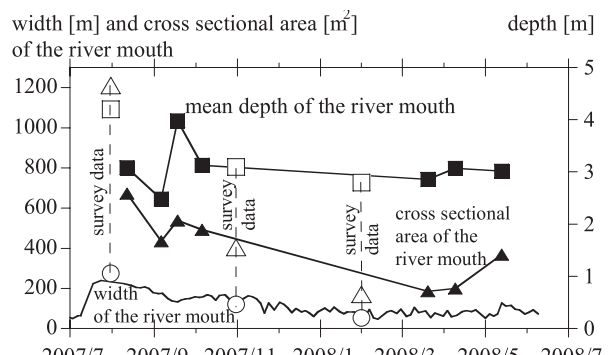

図-10 河口幅（実線）と推定された河口水深（口), 河口断 面積 (A) の変化. 白抜の記号は測量結果.

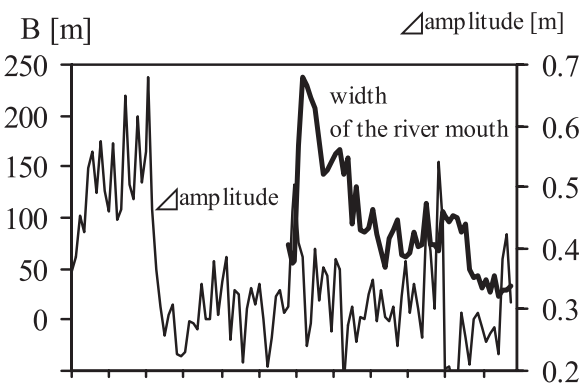

(a)

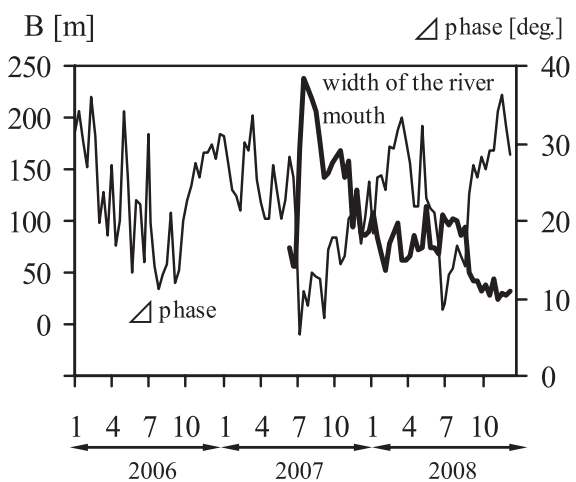

(b)

図-11 $\eta_{\mathrm{K}}$ と $\eta_{\mathrm{O}}$ の $\mathrm{M}_{2}$ 成分の（a）振幅差，(b) 位相差，レーダ より読み取った河口幅の経時変化 
面積 $A$ が大きく変化しないとみなせる期間（約 3 日間） において毎時の $R_{i}$ を求め, 期間中の $R_{i}^{2}$ の総和が最小とな るように $h$ を求めた.

$R_{i}=C_{R i}-\left(\sqrt{g\left(h+\eta_{O i}\right)}-\left(-A \frac{d \eta_{K i}}{d t}+Q_{i}\right) \frac{1}{B\left(h+\eta_{O i}\right)}\right) \cdots(1)$

ここで, $g$ は重力加速度であり, 上式は流れが無い場合 には波が長波の波速で進行することを仮定している。感 潮域面積（河口から約 $4 \mathrm{~km}$ までの範囲， $A=455,000 \mathrm{~m}^{2}$ ) は衛星画像より読み取った。

図-10に2007年から 2008年にかけての7期間について, 河口水深 $h$ および河口断面積 $B h$ を推定した結果を示す. 推定結果が得られた数が限られるのは, レーダ画像に波 の進行が鮮明に捉えられた時期が少なかったためであ る. 推定結果と測量結果は, いずれも数が少ないものの, 砂州決壊後の河口断面積の縮小する経過を捉えている. 砂州の決壊後から翌年3 月にかけて河口水深，河口断面 積とも減少しており，河口部が平水時の形状に近づく様 子が伺える. 2008 年 5 月には出水（鹿島橋ピーク流量 $581 \mathrm{~m}^{3} / \mathrm{s}$ ) があり，hにはほとんど変化がなかったのに対 して河口幅 $B$ が大きくなり, 河口断面積 $B h$ が拡大した. なお, 砂州の決壊（2007年7月15日）後は, 決壊部から も水の出入りがあったため, 2007 年 8 月の推定は信頼性 が劣ると考えられる。

\section{（2）河川水位-潮汐応答の変化}

河道内感潮域水位 $\eta_{K}$ (掛塚橋), 潮位 $\eta_{O}$ (御前崎) の 応答関係を $\mathrm{M}_{2}$ 分潮（周期 12 時間 25 分）に着目して調べ た. 両者の振幅, 位相を高速フーリエ変換で求めた。デ ー夕長は 1 時間毎のデータ 512 時間分（約 21 日）とし, これを10日間隔でシフトしながら，2006年〜2008年の 状況を解析した。

図-11に $\eta_{K}$ と $\eta_{O}$ の $\mathrm{M}_{2}$ 成分の振幅差, 位相差の変化, レ ーダより観測した河口幅の変化を示す．振幅は常に潮汐 が大きく，また，位相も進んでいる。

位相差は河口幅が砂州決壊により拡大する時に顕著に 小さくなり，その後，河口幅の縮小する局面（2007年 7 月から 2008 年 1 月，2008年 9 月から 2008 年 12 月）では 徐々に大きくなっている. これに対して, 振幅差の変化 には河口幅の縮小に伴う明確なトレンドは見られず，む しろ短期的な変動が大きい. 短期的な振幅差変動がもた らされる要因は特定できておらず, 河道の形状, 河口水 深, 砂州の形状などと合わせて詳細に考察をする必要が ある。

2007 年 7 月の砂州決壊, 2008 年 5 月の出水による河口 断面積の拡大局面では位相差, 振幅差共に小さくなって
いる. 2006年 7 月の振幅差, 位相差の変化もこれらに類 似しており，河口断面積の拡大がこの時期にあったこと が伺われる。

\section{6. 結語}

天竜川河口の地形と流動をXバンドレーダにより連続 観測し, 以下の結論を得た。

1）出水により大きく変形した河口部の概形は, 半年で 決壊前とほぼ同じ形状になった。しかしながら, 詳細 に地形変化を調べると, 澪筋部の回復は少なく, 回復 は主に決壊した河口砂州に見られた。

2）河口フロントをレーダ観測で捉えられることを示し， その強度が河川水位の低下する時間帯で大きくなるこ とを示した。

3）河口を進行する波の速さより, 砂州決壊後の河口水 深と断面積の変化を推定した.

4）河口幅の狭広により, 河川内水位と潮位の変動の位 相関係, 振幅差が変化することを示した.

河口フロントについては, 筋状のパターンが1本のみ に着目して解析したが，さらにもう1本が捉えられてい る時間帯もあり, 河口フロントはジェット状に発達して いると考えられる．筋状のパターンの東西方向への凹凸 が定まるメカニズム, 筋状のパターンが到達する沖側の 限界などと河口域の流速場, 河川からの土砂が到達し得 る範囲の関係を解明することが今後の研究課題として挙 げられる。

謝辞：観測に際し静岡県下水道公社西遠浄化センターな らびに日本へルス工業（株）職員の皆様に便宜を図って 頂いた。浜松河川国道事務所には測量データを提供頂い た. 豊橋技術科学大学岡辺拓巳産学官連携研究員・青木 伸一教授に天竜川河口域の観測データの提供を受けた. 本研究は科学技術振興調整費（先端技術を用いた動的土 砂管理と沿岸防災，代表者：青木伸一）の支援を受けた。 以上ここに記して謝意を表します。

\section{参 考 文 献}

武若 聡・高橋 悠・田島芳満・佐藤慩司 (2008) ：Xバン ドレーダによる天竜川河口域の地形と流動の観測, 海岸 工学論文集, Vol. 55, pp. 651-655.

田島芳満 ·高川智博 - 浅野泰史 · 佐藤懭司 - 武若 聡 （2008）：特性の異なる二つの台風による天竜川河口砂州 の大規模変形, 海岸工学論文集, Vol. 55, pp. 646-650.

浜松河川国道事務所, 天竜川ダム再編事業 http://www.cbr.mlit.go.jp/hamamatsu/gaiyo_dam/tenryu.html, 参照2009-05-06. 